\title{
Metabolic Fate of Extracellular NAD in Human Skin Fibroblasts
}

\author{
Maria Francesca Aleo, ${ }^{1}$ Maria Luisa Giudici, ${ }^{1}$ Silvia Sestini, ${ }^{2}$ Paola Danesi, ${ }^{1}$ Giuseppe Pompucci, ${ }^{2}$ \\ and Augusto Preti ${ }^{1}$ \\ ${ }^{1}$ Departament of Biomedical Science and Biotechnology, University of Brescia, 25123 Brescia, Italy \\ ${ }^{2}$ Department of Molecular Biology, University of Siena, 53100 Siena, Italy
}

\begin{abstract}
Extracellular NAD is degraded to pyridine and purine metabolites by different types of surface-located enzymes which are expressed differently on the plasmamembrane of various human cells and tissues. In a previous report, we demonstrated that NAD-glycohydrolase, nucleotide pyrophosphatase and 5'-nucleotidase are located on the outer surface of human skin fibroblasts. Nucleotide pyrophosphatase cleaves NAD to nicotinamide mononucleotide and AMP, and 5'-nucleotidase hydrolyses AMP to adenosine. Cells incubated with NAD, produce nicotinamide, nicotinamide mononucleotide, hypoxanthine and adenine. The absence of ADPribose and adenosine in the extracellular compartment could be due to further catabolism and/or uptake of these products. To clarify the fate of the purine moiety of exogenous NAD, we investigated uptake of the products of NAD hydrolysis using $U-\left[{ }^{14} C\right]$-adenine-NAD. ATP was found to be the main labeled intracellular product of exogenous NAD catabolism; ADP, AMP, inosine and adenosine were also detected but in small quantities. Addition of ADPribose or adenosine to the incubation medium decreased uptake of radioactive purine, which, on the contrary, was unaffected by addition of inosine. ADPribose strongly inhibited the activity of ecto-NAD-hydrolyzing enzymes, whereas adenosine did not. Radioactive uptake by purine drastically dropped in fibroblasts incubated with ${ }^{14} \mathrm{C}-\mathrm{NAD}$ and dipyridamole, an inhibitor of adenosine transport. Partial inhibition of $\left[{ }^{14} \mathrm{C}\right]-\mathrm{NAD}$ uptake observed in fibroblasts depleted of ATP showed that the transport system requires ATP to some extent. All these findings suggest that adenosine is the purine form taken up by cells, and this hypothesis was confirmed incubating cultured fibroblasts with ${ }^{14} \mathrm{C}$-adenosine and analyzing nucleoside uptake and intracellular metabolism under different experimental conditions. Fibroblasts incubated with $\left[{ }^{14} \mathrm{C}\right]$-adenosine yield the same radioactive products as with $\left[{ }^{14} \mathrm{C}\right]-\mathrm{NAD}$; the absence of inhibition of $\left[{ }^{14} \mathrm{C}\right]$-adenosine uptake by ADPribose in the presence of $\alpha-\beta$ methyleneADP, an inhibitor of $5^{\prime}$ nucleotidase, demonstrates that ADPribose coming from NAD via NAD-glycohydrolase is finally catabolised to adenosine. These results confirm that adenosine is the NAD hydrolysis product incorporated by cells and further metabolized to ATP, and that adenosine transport is partially ATP dependent. J. Cell. Biochem. 80:360-366, 2001. ๑ 2001 Wiley-Liss, Inc.
\end{abstract}

Key words: NAD; NAD-glycohydrolase; ectoenzymes; adenosine; uptake; purine; human skin fibroblasts

In all living cells, nicotinamide adenine dinucleotide (NAD) is a cofactor for redox-reactions and substrate for enzymes such as mono and poly-ADP-ribosyl transferase [Ueda and Hayaishi, 1985], ADP-ribosyl cyclase [Lee and Aarhus, 1991] and NAD-glycohydrolase [Travo et al., 1979]. NAD has also been identified as a synaptic modulator in the central nervous

*Correspondence to: Dr. Maria Francesca Aleo, Sezione di Biochimica, Dipartimento di Scienze Biomediche e Biotecnologie, Università degli studi di Brescia, via Valsabbina, 19, 25123 Brescia, Italy. E-mail: aleo@med.unibs.it

Received 26 May 2000; Accepted 25 July 2000

(C) 2001 Wiley-Liss, Inc.

This article published online in Wiley InterScience, November XX, 2000. system [Snell et al., 1984] and as an inhibitor of excitatory synaptic transmission in the rat hippocampus, acting through activation of specific receptors [Gallareta et al., 1993]. This evidence associated with the presence of NAD in biological fluids [Kim et al., 1993a; Majamaa et al., 1996; De Flora et al., 1996] has revealed much about the physiological functions of this nucleotide.

Extracellular NAD is degraded to pyridine and purine metabolites by different types of surface-located enzymes, which are expressed differently on the plasmamembrane of various human cells and tissues [Zimmermann, 1996; Han et al., 1995]. The main enzyme family is 
the NAD-glycohydrolases. It is NAD specific and hydrolyses NAD to nicotinamide and ADPribose [Bock et al., 1971; Muller et al., 1983; Honma and Mandel, 1986]. In blood cells NAD-glycohydrolase activity is expressed by the transmembrane glycoprotein CD38 [Malavasi et al., 1994], a bifunctional ectoenzyme converting NAD to nicotinamide and cyclic ADPribose (ADP-ribosyl cyclase activity) and cyclic ADPribose to ADPribose (cADPribose hydrolase activity) [Zocchi et al., 1993; Kim et al., 1993b]. Cyclic ADPribose is a newly identified messenger which mobilizes $\mathrm{Ca}^{2+}$ from an inositol 1,4,5-trisphosphate insensitive intracellular store [Berridge, 1993; Lee, 1994; De Flora et al., 1998]. NAD therefore acts as extracellular signaling substance or is a precursor of signaling nucleotides [Kato et al., 1995; Okamoto et al, 1995]. A number of enzymes metabolizing extracellular purine nucleotides and nucleosides may also act on exogenous NAD, influencing its physiological role and the fate of the hydrolysis products [Zimmermann, 1996].

In a previous report [Aleo et al., 1996], we demonstrated that NAD-glycohydrolase, nucleotide pyrophosphatase and $5^{\prime}$-nucleotidase are located on the outer surface of human skin fibroblasts. Nucleotide pyrophosphatase cleaves NAD to nicotinamide mononucleotide and AMP, and 5'-nucleotidase hydrolyses AMP to adenosine. Cells incubated in the presence of $\mathrm{NAD}$, produced nicotinamide, nicotinamide mononucleotide (NMN), hypoxanthine and adenine but not ADPribose and adenosine (probably due to uptake and further catabolism of these products).

To clarify the fate of the purine moiety of exogenous NAD and its role in the intracellular metabolism of purines, we investigated the uptake and reutilization of NAD-hydrolysis products, using U-[ $\left[{ }^{14} \mathrm{C}\right]$-adenine-NAD.

\section{METHODS}

\section{Materials}

Minimum essential medium with Earle's salts (MEM), glutamine, trypsin, and foetal calf serum were from Life Technologies Italia S.r.l. (Gibco BRL). NAD, adenine, adenosine, ADPribose, AMP, ADP, ATP, IMP, inosine, hypoxanthine, dipyridamole, nitrobenzylthioinosine, 2-deoxy-D-glucose, ouabaine, 1,N6etheno-NAD and methyleneadenosine $5^{\prime}$-dip- hosphate were from Sigma-Aldrich S.r.l. (Milan, Italy). $\mathrm{NaN}_{3}$ was from Merck (Bracco S.p.A, Milan, Italy). Methanol and tetrabutylammonium dihydrogen phosphate (TBA) were from Carlo-Erba (Milan, Italy).

\section{Cell Culture}

Human skin fibroblasts were grown in $35 \mathrm{~mm}$ dishes containing MEM medium with $10 \%$ foetal calf serum and $2 \mathrm{mM}$ L-glutamine in a $5 \% \mathrm{CO}_{2}$ atmosphere at $37^{\circ} \mathrm{C}$.

\section{Enzyme Assays}

Ecto-NAD-hydrolyzing activities (NAD-glycohydrolase and nucleotide pyrophosphatase) were measured by a fluorimetric method described by Muller et al. [1983]: confluent fibroblasts were incubated $10 \mathrm{~min}$ at $37^{\circ} \mathrm{C}$ in the presence of $0.2 \mathrm{mM}$ 1,N6-etheno-NAD in $500 \mu \mathrm{l}$ phosphate buffered saline (PBS); $400 \mu \mathrm{l}$ of incubation medium was diluted with the same volume of PBS and fluorescence measured. In some experiments, $1 \mathrm{mM}$ ADPribose or adenosine or $5 \mathrm{mM} \mathrm{NaN}_{3}$ and $50 \mathrm{mM}$ 2-deoxyglucose $\left(\mathrm{NaN}_{3} / \mathrm{dxg}\right)$ were added to the incubation medium. Fluorescence was measured using a Jasco FP-770 Spectrofluorimeter exciting at $290 \mathrm{~nm}$ and reading at $415 \mathrm{~nm}$.

\section{Determination of ATP in Controls and ATP-Depleted Cells}

Depletion of ATP intracellular levels was achieved incubating fibroblasts at $37^{\circ} \mathrm{C}$ with $10 \mathrm{mM}$ Hepes in Hank's buffer $\mathrm{pH} 7.4(\mathrm{H} / \mathrm{H}$ buffer) without glucose but containing $\mathrm{NaN}_{3} /$ dxg. After 15, 30, 75 and $90 \mathrm{~min}$, cells were harvested by scraping in $0.1 \mathrm{~N} \mathrm{HClO}_{4}$, the cellular extracts centrifuged for $15 \mathrm{~min}$ at $12,000 \mathrm{~g}$ in an Eppendorf 5414 centrifuge and the supernatants neutralized with $1.33 \mathrm{M} \mathrm{K}_{2} \mathrm{CO}_{3}$. The ATP, ADP and AMP contents of the final clear supernatant were analyzed by HPLC. Protein determination was performed by Bradford assay [Bradford, 1976] on the first pellet resuspended in $1 \mathrm{M} \mathrm{NaOH}$. Control cells were incubated for the same times with $\mathrm{H} / \mathrm{H}$ buffer.

HPLC analysis was performed as previously described [Aleo et al. 1996] using 0.1 M K-phosphate buffer containing $6 \mathrm{mM}$ TBA at $\mathrm{pH} 5.5$ and methanol as eluants.

\section{${ }^{14} \mathrm{C}$-NAD and ${ }^{14} \mathrm{C}$-Adenosine Supply}

Confluent fibroblasts were incubated for $60 \mathrm{~min}$ at $37^{\circ} \mathrm{C}$ with $1 \mu \mathrm{M} \mathrm{U}$ - $\left[{ }^{14} \mathrm{C}\right]$-adenine- 
$\mathrm{NAD}(252 \mathrm{mCi} / \mathrm{mmol}$, Amersham International plc, England) or $1 \mu \mathrm{M} \quad 8-\left[{ }^{14} \mathrm{C}\right]$ adenosine $(58 \mathrm{mCi} / \mathrm{mmol} \mathrm{NEN}$ Life Science Products Italy S.r.l.) in $\mathrm{H} / \mathrm{H}$ buffer. The reaction was stopped by chilling cells at $0^{\circ} \mathrm{C}$. After washing, cells were harvested by scraping with $70 \%$ (v/v) ethanol and centrifuged for $10 \mathrm{~min}$ at $14,000 \mathrm{~g}$ in a Hermle Z 230 MA centrifuge. Pellets were resuspended with 1 volume of $18 \%$ trichloroacetic acid and dissolved with 2 volume of $1 \mathrm{M} \mathrm{NaOH}$, while supernatants were evaporated to $80 \mu \mathrm{l}$ in a speed-vac centrifuge (Howe, Gyrovap L) and then used for thin layer chromatography analysis. Aliquots of supernatant or pellet were measured in a Wallac Win Spectral TM 1414 Liquid Scintillation Counter.

ADPribose or adenosine or inosine or dipyridamole (DPR) or nitrobenzylthioinosine (NBT) $(100 \mu \mathrm{M})$ were added to the incubation medium where indicated.

Protein content of $\mathrm{NaOH}$ dissolved pellets was determined according to Bradford [Bradford, 1976] using bovine serum albumin as standard.

\section{TLC Analysis and Autoradiography}

The labeled products were estimated by TLC using iso-butyric acid/ $\mathrm{H}_{2} \mathrm{O} / \mathrm{NH}_{3}$ (66:33:1.7 $\mathrm{v} / \mathrm{v} / \mathrm{v}$ ) as solvent system. Suitable unlabeled internal standards were used and visualised by UV fluorescence. Autoradiography of plates was detected with Hyperfilm-MP X-ray (Amersham) and the radioactive spots were scraped and quantified by liquid scintillation count.

\section{RESULTS}

When human skin fibroblasts were incubated $60 \mathrm{~min}$ at $37^{\circ} \mathrm{C}$ with $\mathrm{H} / \mathrm{H}$ buffer containing $1 \mu \mathrm{M} \quad \mathrm{U}-\left[{ }^{14} \mathrm{C}\right]$-adenine-NAD $(150 \mathrm{nCi} /$ dish $)$, $25 \pm 3.0 \%$ of the total radioactivity, or $1.27 \pm 0.1 \mathrm{nmol} / \mathrm{mg}$ protein, was incorporated by the cells $(n=12)$. TLC analysis of cell extracts revealed that the labeled species were mainly ATP (79.97\%) and ADP plus IMP (11.86\%); trace amounts of NAD (1.45\%), AMP (1.67\%) and other purines such as adenosine, inosine and hypoxanthine $(2.17,2.23$, and $0.64 \%$, respectively) were also present.

The main purine products of extracellular NAD hydrolysis in fibroblasts [Aleo et al., 1996], namely ADPribose and adenosine were then added to the incubation medium contain-

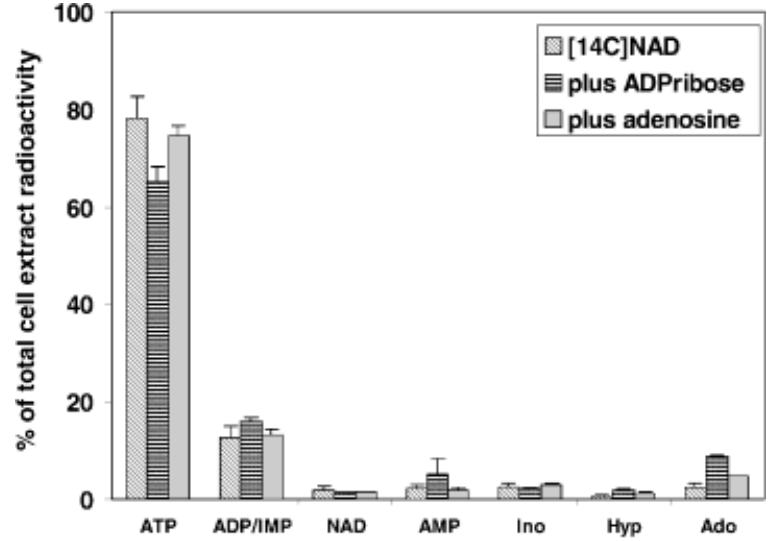

Fig. 1. Distribution of intracellular radioactive adenine compounds after incubation of fibroblasts for $1 \mathrm{~h}$ with $1 \mu \mathrm{MU}-\left[{ }^{14} \mathrm{C}\right]-$ adenine-NAD in the presence or absence of $100 \mu \mathrm{M}$ ADPribose or adenosine. Values are given as percentage of total cell extract radioactivity.

ing $\mathrm{U}-\left[{ }^{14} \mathrm{C}\right]$-adenine-NAD. Total radioactive cell uptake drastically decreased to $3.6 \pm 0.9 \%$ in the presence of ADPribose and $5.0 \pm 0.76 \%$ in the presence of adenosine $(n=5)$, while the relative proportion of intracellular labeled compounds did not vary with respect to control cells (Fig. 1). Thus, extracellular ADPribose and adenosine interfere in the uptake of radioactivity, but do not modify ${ }^{14} \mathrm{C}$-purine recycling.

ADPribose is a known inhibitor of NAD glycohydrolase [Honma and Mandel, 1986] and it competes with NAD as a substrate of nucleotide pyrophosphatase. When added to the incubation medium of the NAD-hydrolytic ectoenzyme assay, ADPribose strongly inhibited their activity, but adenosine did not (Table I). This suggests that ADPribose and adenosine affect $\left[{ }^{14} \mathrm{C}\right] \mathrm{NAD}$ uptake differently: ADPribose competes with $\left[{ }^{14} \mathrm{C}\right] \mathrm{NAD}$ in the production of the radioactive purine moiety, which is then only partially taken up, whereas adenosine competes directly with the latter compound for membrane passage, without affecting the ectoenzymes.

Uptake of the ${ }^{14} \mathrm{C}$-purine moiety was also measured in the presence of the purine nucleoside inosine, or DPR, an inhibitor of adenosine transport. Uptake was reduced to $2.1 \pm 0.6 \%$ per $100 \mu \mathrm{M} \mathrm{DPR}$, and $19.5 \pm 2.4 \%$ per $100 \mu \mathrm{M}$ inosine $(n=4)$. All these results suggest that adenosine is the molecule involved in purine moiety uptake by NAD. 
TABLE I. Assay of Membrane NAD-Hydrolase Activities (NAD-Glycohydrolase and Nucleotide Pyrophosphatase) in Human Skin Fibroblast ${ }^{\mathrm{a}}$

\begin{tabular}{lccc}
\hline Control & $\begin{array}{c}+ \text { ADPribose } \\
(1 \mathrm{mM})\end{array}$ & $\begin{array}{c}+ \text { Adenosine } \\
(1 \mathrm{mM})\end{array}$ & $\begin{array}{c}+\mathrm{NaN}_{3}(5 \mathrm{mM}) \\
+\mathrm{dxg}(50 \mathrm{mM})\end{array}$ \\
\hline $\begin{array}{l}184,30 \pm 36,60 \\
(\mathrm{n}=6)\end{array}$ & $\begin{array}{c}00,00 \pm 0,00 \\
(\mathrm{n}=6)\end{array}$ & $\begin{array}{c}146,70 \pm 15,00 \\
(\mathrm{n}=4)\end{array}$ & $\begin{array}{c}166,30 \pm 10,30 \\
(\mathrm{n}=5)\end{array}$ \\
\hline
\end{tabular}

${ }^{\mathrm{a}}$ Cells were incubated for $10 \mathrm{~min}$ at $37^{\circ} \mathrm{C}$ in the presence of $0.2 \mathrm{mM} 1$,N6etheno-NAD with or without ADPribose or Adenosine or $\mathrm{NaN}_{3} / \mathrm{dxg}$ (in the indicated amounts). Activity is expressed as fluorescence units $(\Delta \mathrm{F} / \mathrm{min})$ per $\mathrm{mg}$ of protein.

*Cells were preincubated for $15 \mathrm{~min}$ at $37^{\circ} \mathrm{C}$ in $10 \mathrm{mM}$ Hanks'/Hepes buffer $\mathrm{pH} 7.4$ without glucose and in the presence of $\mathrm{NaN}_{3} / \mathrm{dxg}$ before addition of 1 , N6etheno-NAD.

\section{Effect of ATP Depletion on $\mathrm{U}-\left[{ }^{14} \mathrm{C}\right]$-Adenine-NAD Uptake}

The effect of ATP depletion on radioactivity uptake was also examined. When fibroblasts were incubated with $\mathrm{H} / \mathrm{H}$ buffer without glucose, with $5 \mathrm{mM} \mathrm{NaN}$ and $50 \mathrm{mM}$ deossyglucose, $73 \%$ of the energy charge of the adenylate pool, as defined by Atkinson formula [Atkinson, 1977], was lost after $15 \mathrm{~min}$ and reached a minimum (9\%) after 75 min. Figure 2 shows the time course of cell content of AMP, ADP and ATP assayed by HPLC. After 15 min of $\mathrm{NaN}_{3} /$ $\mathrm{dxg}$ treatment, $1 \mu \mathrm{M}\left[{ }^{14} \mathrm{C}\right] \mathrm{NAD}$ was added and $60 \mathrm{~min}$ later the radioactivity of cell extracts was measured. These ATP-depletion conditions reduced the uptake of total ${ }^{14} \mathrm{C}$-purine to $13.0 \pm 1.5 \%$, which is $54.7 \pm 5.3 \%(\mathrm{n}=6)$ of the value found in untreated controls, and modified

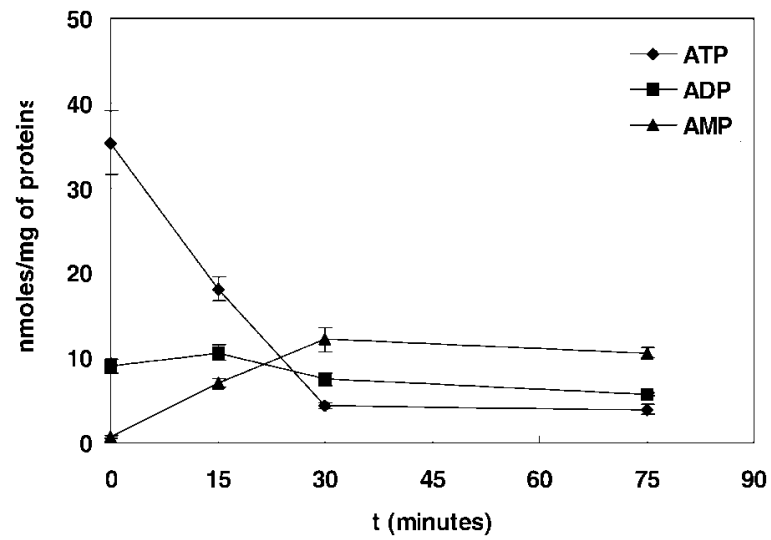

Fig. 2. Time course of ATP, ADP and AMP content in cell extract (nmol/mg of protein), after incubation with $5 \mathrm{mM} \mathrm{NaN}_{3}$ and $50 \mathrm{mM} \mathrm{dxg}$ in $\mathrm{H} / \mathrm{H}$ buffer without glucose. Data of a representative experiment, made in duplicate, are shown.

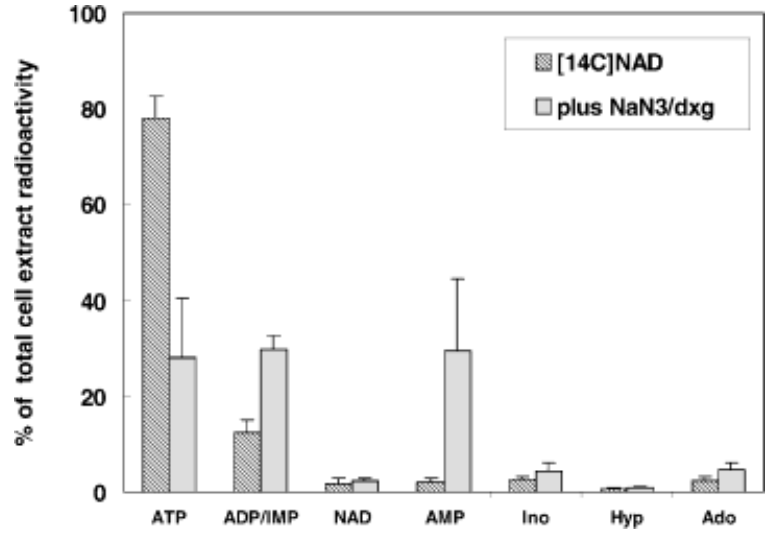

Fig. 3. Distribution of radioactive adenine compounds in cell extract of ATP-depleted fibroblasts. Cells were incubated for $15 \mathrm{~min}$ in $\mathrm{H} / \mathrm{H}$ buffer without glucose containing $\mathrm{NaN}_{3} / \mathrm{dxg}$, then $1 \mu \mathrm{MU}-\left[{ }^{14} \mathrm{C}\right]$-adenine-NAD was added and after $1 \mathrm{~h}$ the radioactivity of the different adenine compounds was measured. Control cells were incubated in $\mathrm{H} / \mathrm{H}$ without $\mathrm{NaN}_{3} / \mathrm{dxg}$. Values are given as percentage of total cell extract radioactivity.

intracellular radioactivity distribution (Fig. 3). The recycling of labeled purine matches the behavior of adenine nucleotides observed in time-course experiments: ATP production was inhibited, and AMP accumulated. The activities of NAD hydrolyzing ectoenzymes were not affected by incubation with $\mathrm{NaN}_{3} / \mathrm{dxg}$ (Table I). These results suggest that transport of $\mathrm{U}-\left[{ }^{14} \mathrm{C}\right]$ adenine-NAD requires ATP to some extent.

\section{$\left[{ }^{14} \mathrm{C}\right]$-Adenosine Uptake}

To confirm that adenosine is the NAD moiety responsible for $\left[{ }^{14} \mathrm{C}\right]$-purine uptake, fibroblasts were incubated in the presence of $1 \mu \mathrm{M} 8-\left[{ }^{14} \mathrm{C}\right]$ adenosine $(35 \mathrm{nCi} /$ dish $)$. Uptake of $\left[{ }^{14} \mathrm{C}\right]$-adenosine was linear with time for at least $30 \mathrm{~min}$, 


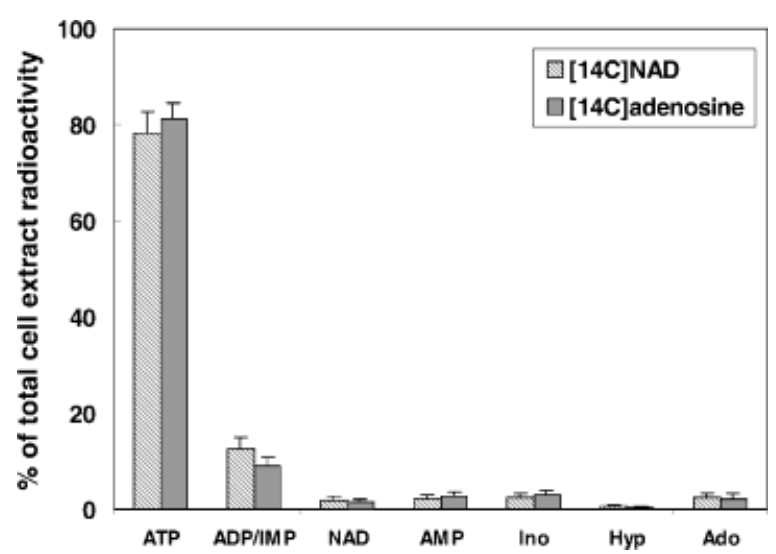

Fig. 4. Distribution of intracellular radioactive adenine compounds after incubation of human fibroblasts for $1 \mathrm{~h}$ with $1 \mu \mathrm{M}$ $\mathrm{U}-\left[{ }^{14} \mathrm{C}\right]$-adenosine. Values are given as percentage of total cell extract radioactivity.

reaching $1.46 \pm 0.26 \mathrm{nmol} / \mathrm{mg}$ protein at $60 \mathrm{~min}$ $(33.7 \pm 5.6 \%$ of total radioactivity, $\mathrm{n}=10)$, when cell extract radioactivity showed a same pattern of purine compounds identical to that detected after incubation with $\left[{ }^{14} \mathrm{C}\right] \mathrm{NAD}$ (Fig. 4). $\left[{ }^{14} \mathrm{C}\right]$-adenosine uptake was completely depressed by two inhibitors of equilibrative nucleoside transport, namely $10 \mu \mathrm{M}$ DPR or $10 \mu \mathrm{M}$ NBT; being $1.64 \pm 0.8$ and $1.2 \pm 0.1 \%$ of total radioactivity, respectively $(\mathrm{n}=6)$. To determine whether the uptake was affected by cell content of ATP, the effect of $\mathrm{NaN}_{3} / \mathrm{dxg}$ treatment on $\left[{ }^{14} \mathrm{C}\right]$-adenosine uptake was assessed. A decrease cell radioactivity to $17 \pm 2.0 \%$ $(\mathrm{n}=6)$ was found. To verify adenosine active transport in human fibroblasts, the uptake assays were carried out substituting extracellular $\mathrm{Na}^{+}$with equimolar choline, which eliminates concentrative $\mathrm{Na}^{+}$-dependent adenosine permeation, or inhibiting $\mathrm{Na}^{+}, \mathrm{K}^{+}$-ATPase by $2 \mathrm{mM}$ ouabain, that dissipated the electrochemical gradient of $\mathrm{Na}^{+}$. The effects were less than those obtained with $\mathrm{NaN}_{3} /$ dxg treatment, leading to $\left[{ }^{14} \mathrm{C}\right]$-adenosine uptakes of $25.27 \pm 1.0$ and $26.9 \pm 1.0 \%$, respectively $(\mathrm{n}=4)$. Finally, the effect of exogenous ADPribose on $\left[{ }^{14} \mathrm{C}\right]$-adenosine uptake was tested. $\left[{ }^{14} \mathrm{C}\right]$ nucleoside transport was reduced to $19.71 \pm 3.84 \%$ of total radioactivity in the presence of $100 \mu \mathrm{M}$ ADPribose $(\mathrm{n}=6)$. This inhibition was removed when the incubation medium was supplemented with $1 \mathrm{mM} \alpha-\beta$ methyleneADP, an inhibitor of $5^{\prime}$-nucleotidase. $\alpha-\beta$ methyleneADP was ineffective when incubated with $\left[{ }^{14} \mathrm{C}\right]$ adenosine alone, but when added to U-[ $\left[{ }^{14} \mathrm{C}\right]$-adenine-NAD uptake assay mixture, strongly depressed uptake $(2.7 \pm$ $0.4 \%, \mathrm{n}=2$ ) thus demonstrating that adenosine is the purine moiety of NAD which permeates the cell membrane.

\section{DISCUSSION}

In a previous study, we demonstrated that NAD-glycohydrolase (cleaving NAD into nicotinamide and ADPR), nucleotide pyrophosphatase (cleaving NAD into NMN and AMP), and $5^{\prime}$-nucleotidase are the enzymes involved in extracellular NAD catabolism in human skin fibroblasts. We also showed that the final products of the extracellular NAD metabolism are nicotinamide, NMN, hypoxanthine and adenine [Aleo et al., 1996]. In the present study, we investigated the metabolic fate of the extracellular NAD purine moiety, showing that adenosine is the form which permeates the cell membrane.

This hypothesis is supported by the competition observed between ADPribose or adenosine and $\left[{ }^{14} \mathrm{C}\right]-\mathrm{NAD}$ for uptake of the purine moiety into cells and by the drastic reduction in uptake of labeled purine with an inhibitor of adenosine transport such as DPR in the extracellular medium. Moreover, fibroblasts incubated with $\left[{ }^{14} \mathrm{C}\right]$-adenosine yield the same radioactive products as with $\left[{ }^{14} \mathrm{C}\right]-\mathrm{NAD}$. The fact that ADPribose does not inhibit $\left[{ }^{14} \mathrm{C}\right]$-adenosine uptake in the presence of $\alpha-\beta$ methyleneADP, an inhibitor of $5^{\prime}$-nucleotidase, demonstrates that ADPribose produced from NAD via NADglycohydrolase is finally catabolised to adenosine. The product of NAD degradation via nucleotide pyrophosphatase, AMP, has the same fate, being converted by $5^{\prime}$ nucleotidase into adenosine, which enters the cell. Most of the adenosine incorporated into fibroblasts is then phosphorylated and metabolized via AMP to ADP and ATP (90\%). The extracellular fates of NAD suggested by our results are summarized in Figure 5.

The partial inhibition of $\left[{ }^{14} \mathrm{C}\right]-\mathrm{NAD}$ uptake observed in fibroblasts depleted of ATP shows that the adenosine transport system requires ATP to some extent. The main transport of nucleosides into the cells is known to be equilibrative (by facilitated diffusion) or concentrative $\left(\mathrm{Na}^{+}\right.$linked) [Dagnino et al., 1991; Gu et al., 1996]. Adenosine kinase, which causes phosphorylation of adenosine, plays a role in 


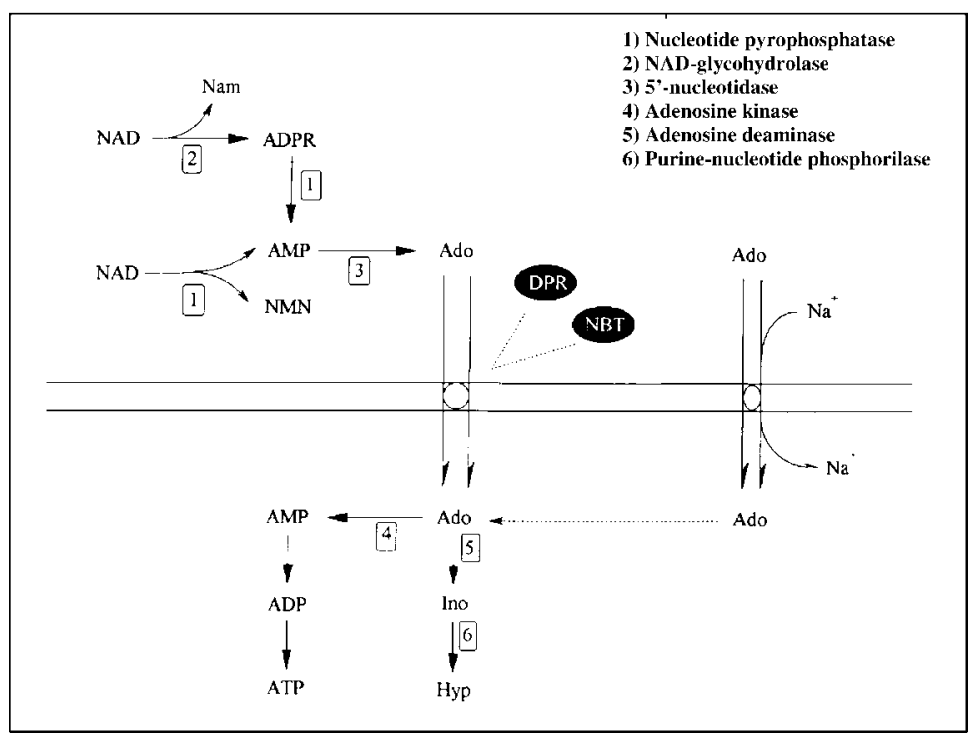

Fig. 5. Extracellular fates of NAD in human fibroblasts.

nucleotide uptake. In our experiments with human fibroblasts, uptake of $\left[{ }^{14} \mathrm{C}\right]$-adenosine was completely inhibited by DPR as well as by NBT, known inhibitors of equilibrative nucleoside transport, and was partially inhibited in ATP depleted cells, to the same extent as previously observed for $\left[{ }^{14} \mathrm{C}\right]-\mathrm{NAD}$. Choline and ouabaine, which depress $\mathrm{Na}^{+}$-dependent adenosine permeation and the electrochemical gradient respectively, slightly inhibited uptake of $\left[{ }^{14} \mathrm{C}\right]$-adenosine, showing that some adenosine (about $20-25 \%$ of total uptake) may enter fibroblasts by active transport.

All these findings indicate that adenosine is the main transport form of the purine moiety of NAD, when NAD is metabolized by extracellular enzymes. Passive transport of NAD was recently demonstrated [Zocchi et al., 1999]; the flux across the membranes depended only on the concentration gradient and did not seem to require any energy source. The cells used for the above experiments (HeLa and 3T3 cell lines) were previously shown to be devoid of any NAD hydrolyzing activity. We cannot exclude the possibility that in human fibroblasts, in which NAD hydrolyzing activities do exist, a small amount of NAD permeates the membranes by a similar transport mechanism. The novel finding demonstrated in this study with human fibroblasts is that NAD is cleaved by extracellular enzymes, and the purine form which is taken up is adenosine.

\section{ACKNOWLEDGMENTS}

This work was financed by the Italian Ministry of Universities and Scientific and Technological Research (MURST funds 60\%).

\section{REFERENCES}

Aleo MF, Sestini S, Pompucci G, Preti A. 1996. Enzymatic activities affecting exogenous nicotinamide adenine dinucleotide in human skin fibroblasts. J Cell Physiol 167:173-176.

Atkinson DE. 1977. Cellular energy metabolism and its regulation. New York: Academic Press.

Berridge MJ. 1993. A tale of two messengers. Nature 365: 388-389.

Bock KW, Siekevitz P, Palade GE. 1971. Localization and turnover studies of membrane nicotinamide adenine dinucleotide glycohydrolase in rat liver. J Biol Chem 38:20-24.

Bradford MM. 1976. A rapid and sensitive method for quantitation of microgram quantities of protein utilizing the principle of protein-dye binding. Anal Biochem 72: 248-254

Dagnino L, Bennet LL Jr, Paterson ARP. 1991. Sodiumdependent nucleoside transport in mouse leukemia L1210 cells. J Biol Chem 266:6308-6311.

De Flora A, Guida L, Franco L, Zocchi E, Pestarino M, Usai C, Marchetti C, Fedele E, Fontana G, Raiteri M. 1996. Ectocellular in vitro and in vivo metabolism of cADPribose in cerebellum. Biochem J 320:665-672.

De Flora A, Franco L, Guida L, Bruzzone S, Zocchi E. 1998. Ectocellular CD-38 catalyzed synthesis and intracellular $\mathrm{Ca}^{2+}$-mobilizing activity of cyclic ADP-ribose. Cell Biochem Biophys 28:45-62.

Gallareta M, Solis JM, Menendez N, Conejero C, Martin del Rio R. 1993. Nicotinamide adenine dinucleotides mimic 
adenosine inhibition on synaptic transmission by decreasing glutamate release in rat hippocampal slices. Neuroscience Lett 159:55-58.

Gu JG, Nath A, Geiger JD. 1996. Characterization of inhibitor-sensitive and inhibitor-resistant adenosine transporters in cultured human fetal astrocytes. J Neurochem 67:972-977.

Han MK, Kim JH, Lee DG, Kim UH. 1995. Immunohistochemical localization of NAD glycohydrolase in human and rabbit tissue. Histochem Cell Biol 104:185-189.

Honma T, Mandel P. 1986. $\mathrm{NAD}^{+}$glycohydrolase of the plasmamembrane prepared from glial and neuronal cells. J Neurochem 47:972-975.

Kato I, Takasawa S, Akabane A, Tanaka O, Abe H, Takamura T, Suzuki Y, Nata K, et al. 1995. Regulatory role of CD 38 (ADP-ribosyl cyclase/cyclic ADP-ribose hydrolase) in insulin secretion by glucose in pancreatic cells. J Biol Chem 270:30045-30050.

Kim UH, Han MK, Park BH, Kim HR, An NH. 1993a. Function of NAD glycohydrolase in ADP-ribose uptake from NAD by human erythrocytes. Biochim Biophys Acta 1178:121-126.

Kim H, Jacobson EL, Jacobson MK. 1993b. Synthesis and degradation of cyclic ADP-ribose by NAD glycohydrolases. Science 261:1330-1333.

Lee HC, Aarhus R. 1991. ADP-ribosyl cyclase: an enzyme that cyclizes $\mathrm{NAD}^{+}$into a calcium-mobilizing metabolite. Cell Regul 2:203-209.

Lee HC. 1994. Cyclic ADP-ribose: a new member of a super family of signalling cyclic nucleotides. Cell Sign 6:591-600.

Malavasi F, Funaro A, Roggero S, Horenstein A, Calosso L, Mehta K. 1994. Human CD38: a glycoprotein in search of a function. Imm Today 15:95-97.
Majamaa K, Rusanen H, Rernes AM, Pytinen J, Hassinen IE. 1996. Increase of blood $\mathrm{NAD}^{+}$and of lactacidemia during nicotinamide treatment of a patient with the MELAS syndrome. Life Science 58:691-699.

Muller HM, Muller CD, Shuber F. 1983. NAD ${ }^{+}$glycohydrolase, an ecto-enzyme of calf spleen cells. Biochem J 212:459-464.

Okamoto H, Takasawa S, Tohgo A. 1995. New aspects of the physiological significance of NAD, poly-ADPribose and cyclic ADP-ribose. Biochimie 77:356-363.

Snell CR, Snell PH, Richards CD. 1984. Degradation of NAD by synaptosomes and its inhibition by nicotinamide mononucleotide: implication for the role of NAD as a synaptic modulator. J Neurochem 43:1610-1615.

Travo P, Muller H, Shuber F. 1979. Calf spleen NAD glycohydrolase. Comparison of the catalytic properties of the membrane-bound and the hydrosoluble forms of the enzyme. Eur J Biochem 96:141-149.

Ueda K, Hayaishi O. 1985. ADP-ribosylation. Annu Rev Biochem 54:73-100.

Zimmermann H. 1996. Extracellular purine metabolism. Drug Develop Res 39:337-352.

Zocchi E, Franco L, Guida L, Benatti U, Bargellesi A, Malavasi F, Lee HC, De Flora A. 1993. A single protein immunologically identified as CD38 displays $\mathrm{NAD}^{+}$ glycohydrolase, ADP-ribosyl cyclase and cyclic ADPribose hydrolase activities at the outer surface of human erythrocytes. Biochem Biophys Res Comm 196:14591465.

Zocchi E, Usai C, Guida L, Franco L, Bruzzone S, Passalacqua M, De Flora A. 1999. Ligand-induced internalization of CD38 results in intracellular $\mathrm{Ca}^{2+}$ mobilization: role of $\mathrm{NAD}^{+}$transport across cell membrane. FASEB J 13:273-283. 